\title{
The Predictability of Real Estate Returns and Market Timing
}

\author{
Jianping Mei \\ New York University \\ Crocker H. Liu \\ New York University
}

\begin{abstract}
Recent evidence suggests that all asset returns are predictable to some extent with excess returns on real estate relatively easier to forecast. This raises the issue of whether we can successfully exploit this level of predictability using various market timing strategies to realize superior performance over a buy-and-hold strategy. We find that the level of predictability associated with real estate leads to moderate success in market timing, although this is not necessarily the case for the other asset classes examined in general. Besides this, real estate stocks typically have higher trading profits and higher mean risk-adjusted excess returns when compared to small stocks as well as large stocks and bonds even though most real estate stocks are small stocks.
\end{abstract}

Key words: Market timing, predictability, trading profits, real estate securities

\section{Introduction}

Prior research on exchange traded real estate firms have found that these firms do not earn abnormal returns. Recent evidence, however, suggests that the variation in the expected excess real estate returns over time is predictable and is the result of changes in business conditions ${ }^{1}$ Moreover, one of these studies find that real estate returns are more predictable relative to the returns on other assets. This raises the possibility that real estate might exhibit superior investment performance when compared to other assets if an investor is successful in markettiming. The purpose of the present study, therefore, is to explore whether superior real estate investment performance is possible through a market timing strategy given that we're able to forecast real estate returns. The present study is distinctive from previous real estate investment studies in that no other study explicitly addresses the ability to market time in exchange traded real estate firms (although Glascock, 1991, does use a model similar in spirit to a market timing model to test for changes in portfolio betas during up markets and down markets). The ability to successfully use market timing to achieve superior performance is of interest to practitioners since it suggests a more efficient method to allocate investment funds. Market timing is also of interest to academics not only given the theoretical implications

\footnotetext{
${ }^{1}$ See for example Gyourko and Keim (1991) and Liu and Mei (1990) who find that common factors are likely to drive returns on both real estate and nonreal estate related assets.
} 
associated with the optimal amount of real estate to hold in a portfolio but also given the findings of Gyourko and Keim (1990). They find that returns on real estate investment trusts (REITs) and real estate related companies can predict returns on the Frank Russell Company (FRC) appraisal based return index of unlevered institutional grade properties that most institutional investors use as the return benchmark for direct real estate investment.

This study is also unique from previous finance literature on market timing in that previous studies have focused on testing for the existence of market timing ability within the sample. More specifically, the issue investigated is whether differential investment performance is due to stock selection (micro-forecasting) or the ability to market time (macro-forecasting). The current study, in contrast, focuses on whether the degree of predictability associated with various asset returns and real estate is sufficient to allow an investor to construct a market timing strategy that would lead to superior investment performance. ${ }^{2}$

Our study employs the multi-factor latent-variable model of Lin and Mei (1992) to predict the time variation of expected excess returns on various asset classes. To prevent the in-sample bias problem of using the same data to both estimate the parameters and test the model, a 10year rolling regression is used to form out-of-sample excess return forecasts. Given these return forecasts, three investment strategy portfolios are formed for each asset class including a passive buy and hold portfolio, a portfolio of long and short positions, and a portfolio of long positions. This methodology has several advantages over previous investment performance studies that test for the presence of market timing ability. First, it allows for time-varying risk premiums. The existing methodology of Henriksson-Merton (HM) (1981) assumes that risk premiums are stationary. Another problem with the HM model that our methodology obviates is the possibility of misspecification of the return-generating process due to a misspecification of the market portfolio since the present model makes no assumptions about the observability of systematic factors in the economy. In addition, our model appears to be relatively robust to which set of factors are used to forecast returns; Henriksson (1984) finds that omission of relevant factors is influential in explaining the behavior of returns. Our model also differs from the HM model and the Cumby-Modest (1987) extension of the HM model in that we explicitly develop market-timing strategies according to whether the excess return forecast for an asset is positive or negative. In the market-timing model of Merton (1981), on which most empirical studies are based, the emphasis is on the probability of a correct return forecast. Our model emphasis is on the economic significance (trading profits) of return forecasts.

\footnotetext{
${ }^{2}$ The market timing studies of Henriksson (1984) and Chang and Lewellen (1984) find that few mutual fund managers are able to successfully use market timing to outperform a passive buy and hold investment strategy using the Henriksson and Merton (1981) market timing modifications to the model of Jensen (1968). More recently, Cumby and Modest 0987) generalize the Henriksson-Merton model by relaxing the assumption that the probability of a correct forecast and the magnitude of subsequent market returns need to be independent of each other and find strong evidence that portfolio managers exhibit market timing ability.
} 
The most important finding of our study is that the level of predictability associated with real estate is sufficient for successful market timing to occur. However, this is not necessarily the case for the other asset classes examined. In addition, the mean risk adjusted excess returns on a value-weighted portfolio consisting of various categories of exchange traded real estate firms appears to outperform large-cap stocks, small-cap stocks, bonds, and S\&P 500 benchmark portfolio as well as the passive buy and hold real estate portfolio over the entire out-of-sample period when an active market-timing strategy is employed. In terms of individual real estate stocks, homebuilders have the highest mean risk adjusted excess return when either active trading tactic is chosen with a phenomenal $2.2 \%$ excess return per month on average realized using a long and short trading scheme. More moderate mean excess returns are obtained (at least .78\% per month) in contrast for mortgage REITs, which have the poorest performance of all the real estate categories.

The rest of the paper is organized as follows: Section 2 briefly outlines the framework used for predicting asset returns. Section 3 describes the data utilized while the empirical results are found in section 4 . Section 5 presents our summary and conclusions.

\section{Method for Predicting Asset Returns}

The condition excess return forecast model used in the current study follows from Liu and Mei $(1991,1992)$ and assumes that the expected excess return conditional on information at time $t$, $\boldsymbol{E}_{\boldsymbol{t}}\left[\tilde{\boldsymbol{r}}_{\boldsymbol{i}, \boldsymbol{t}+\mathbf{1}}\right]$, is linear in the economic state variables known to investors at time $\boldsymbol{t}^{3}$

Mathematically,

$$
E_{t}\left[\tilde{r}_{i, t+1}\right]=\sum_{n=1}^{L} \alpha_{i n} X_{n t}
$$

where $\boldsymbol{X}_{\boldsymbol{n} \boldsymbol{t}}, \boldsymbol{n}=\mathbf{1} \ldots \mathrm{L}$, is a vector of $\mathbf{L}$ forecasting variables ( $\boldsymbol{X}_{\boldsymbol{l t}}$ is a constant), which are known to the market at time $t$. A more detailed discussion of the methodology is located in the appendix. The forecasting variables used in the current study include a constant term, a January Dummy, the yield on one-month Treasury bill, the spread between the yields on long-term AAA corporate bonds and the one-month Treasury bill, the dividend yields on the equally-weighted market portfolio, and the cap rate on real estate. The yield variable describes the short-term interest rate while the spread variable depicts the slope of the term structure of interest rates, and the dividend yield variable captures information on expectations about future cash flows and required returns in the stock market. In addition, we also include the cap rate, which

\footnotetext{
${ }^{3}$ A more rigorous derivation of equation (1) using a multi-factor latent variable model is found in Campbell (1987), Ferson (1988), and Liu and Mei (1992) (see appendix). Alternatively, equation (1) is also derivable from a VAR process for asset returns as in Campbell (1991), Campbell and Mei (1992).
} 
captures information on expected future cash flows and required returns on the underlying real estate market. Campbell (1987), Campbell and Hamao (1991), Fama and French $(1988,1989)$, Ferson (1989), Ferson and Harvey (1989), Keim and Stambaugh (1986), among others have used the first three variables in examining the predictability of stocks. Liu and Mei $(1991,1992)$ also find that the cap rate in addition to the preceding three forecasting variables is useful in predicting returns, especially on real estate and small cap stocks. ${ }^{4}$

Although the preceding variable list does not necessarily include all relevant variables that carry information about factor premiums, the methodology that we use is relatively robust to omitted information. A generalized method of moments (GMM) approach, similar to Campbell (1987) and Ferson (1989) is employed to estimate equation 1 to obtain the ex-ante risk premiums on various asset portfolios. Out-of-sample ex-ante excess return forecasts are formed using ten-year rolling GMM regressions with the forecasting variables. For any time period $\boldsymbol{t}$, we estimate equation 1 using data from $\boldsymbol{t} \mathbf{- 1}$ to $\boldsymbol{t} \mathbf{- 1 2 0}$. Then the regression is used to form an excess return forecast, $\boldsymbol{E}_{\boldsymbol{t}}\left[\boldsymbol{e}_{\boldsymbol{i}, \boldsymbol{t}+\mathbf{1}}\right]$, using $\boldsymbol{X}_{\boldsymbol{p} \boldsymbol{t}}$. The excess return forecasts (expected excess return) are calculated for the period 1981.2-1989.4. A passive buy and hold portfolio together with two active portfolios are constructed based on this return forecast: a Long (+) portfolio, and a Long (+) and Short (-) portfolio.

The formation of a Buy and Hold portfolio for each asset class involves assuming that a particular asset category is held over the period 1981.2-1989.12. Construction of the Long (+) portfolio on the other hand, entails taking a long position in a particular asset class whenever the excess return forecast for that asset class is positive, while closing the position and putting the proceeds in treasury bills whenever the excess return forecast for that asset group is negative. Finally, the Long (+) and Short (-) portfolio strategy takes a long position in a particular asset whenever the excess return forecast for that asset is positive, and closing the position and selling short (putting the proceeds from short sales in treasury bills) whenever the excess return forecast on that asset is negative.

\footnotetext{
${ }^{4}$ The cap rate is defined as the ratio of net stabilized earnings to the transaction price (or market value) of a property. Net stabilized income assumes that full lease up of the building has occurred such that the building's vacancy is equal to or less than the vacancy of the market. As such, the cap rote is analogous to the earnings-price ratio on direct real estate investment. Another interpretation of the cap rate is that it represents the weighted average cost of capital (band of investment) for real estate. For example, Nourse (1987) uses this weighted average cost of capital interpretation of the cap rate in testing the impact of income tax changes on income property. We include the cap rate as a forecasting variable since movements in the cap rate do not necessarily contain the same information as fluctuations in the dividend yield on the stock market (e.g., although both the cap rate and dividend yield are measures of income-to-value, the cash flows of buildings are not identical to the cash flows of firms that occupy space in the buildings).
} 


\section{Data}

Asset returns on stocks, bonds, and exchange traded real estate firms are obtained from the Center for Research on Security Prices (CRSP) monthly stock tape for the time period starting Jaunary 1971 and ending April 1989. We use two stock return series. A value-weighted stock index comprised of all New York Stock Exchange (NYSE) and American Stock Exchange (AMEX) stocks is employed as a proxy for stocks with large market capitalizations. We also include a value-weighted small-cap stock index in our study. Both stock return series are taken from the Ibbotson and Associates Stocks, Bonds, Bills, and Inflation (SBBI) series on CRSP. The government bond return series is also obtained from SBBI and represents a portfolio of treasury bonds having an average maturity of 20 years and without call provisions or special tax benefits.

Four value-weighted real estate stock return series are constructed as our proxies for real estate asset returns. Equity real estate investment trusts (EREITs), real estate building companies (Builders), real estate holding companies (Owners), and mortgage real estate investment trusts (Mortgage) comprise the four real estate portfolios. The value-weighted equity and mortgage REIT series are obtained from the National Association of Real Estate Investment Trusts while the Builder and Owner series consist of all real estate companies in the Audit Investment publication The Realty Stock Review. ${ }^{5}$ Besides this, we construct a value weighted as well as an equally weighted portfolio consisting of all four types of real estate securities.

In addition to the returns on four real estate portfolios, monthly returns on the S\&P 500 is used to proxy for the market portfolio and is also used as a comparison benchmark in analyzing the relative behavior of real estate asset returns. The yield on the one-month Treasury bill, the spread between the yields on long-term AAA corporate bonds and the one-month Treasury bill, and the dividend yields on the equally-weighted market portfolio are obtained from the Federal Reserve Bulletin and Ibbotson and Associates (1989). The cap rates on real estate are taken from the American Council of Life Insurance publication Investment Bulletin: Mortgage Commitments on Multifamily and Nonresidential Properties Reported by 20 Life Insurance

\section{Companies.}

\footnotetext{
${ }^{5}$ Two primary classifications exist for a REIT-equity and mortgage. An equity REIT differs from a mortgage REIT in that the former acquires direct equity ownership in the properties while the latter type of REIT purchases mortgage obligations secured by real estate. Both types of REITs are constrained in both the type of real estate activities they can pursue and the management of investments. In contrast to builders for example, REITs are not allowed to develop properties. In contrast to owners on the other hand, REITs are constrained in the number of properties that they can sell in any one period. The list of builders and owners is available from the authors on request.
} 


\section{Empirical Results}

Table 1 reports the summary statistics for each of our asset classes and forecasting variables. An inspection of this table reveals that none of the real estate categories has a higher mean excess return relative to small stocks although both equity REITs and real estate owners have higher excess returns relative to value weighted stocks and government bonds. In contrast, the average return for builders and mortgage REITs are lower than that for stocks and bonds. Within the real estate subgroup, real estate owners have the highest mean excess returns followed by equity REITs. Not surprisingly, the excess returns associated with real estate owners are more volatile relative to small cap stocks, large cap stocks, and bonds. However, homebuilder returns have the widest fluctuations over time. For the study period used, the standard deviation associated with equity REITs is similar to that of large-cap stocks while the total volatility of mortgage REITs is greater than large-cap stocks but less than small stocks. This suggests that any increase in the predictability of various real estate return classes relative to other assets does not arise from relatively lower variations in returns, at least with respect to the current study. Thus, this tends to negate the argument that any superior performance, if any, of real estate relative to other assets arising from market timing is attributable to exchange traded real estate firms having a relatively lower variance. Table 1 also reveals that the returns on all assets exhibit positive first order autocorrelation which is consistent with prior studies.

Table 1 also reports the correlations of returns among four asset classes. As expected, the excess returns on EREITs are highly correlated with small-cap stocks given the prior findings of Liu and Mei (1991). Excess returns for builders, owners, and mortgage REITs also show a tendency to move with excess returns on small cap stocks. In general, the correlation among asset classes is moderate to high except for government bonds which exhibits minimal correlations with all other assets. 
Table 1. Summary statistics.

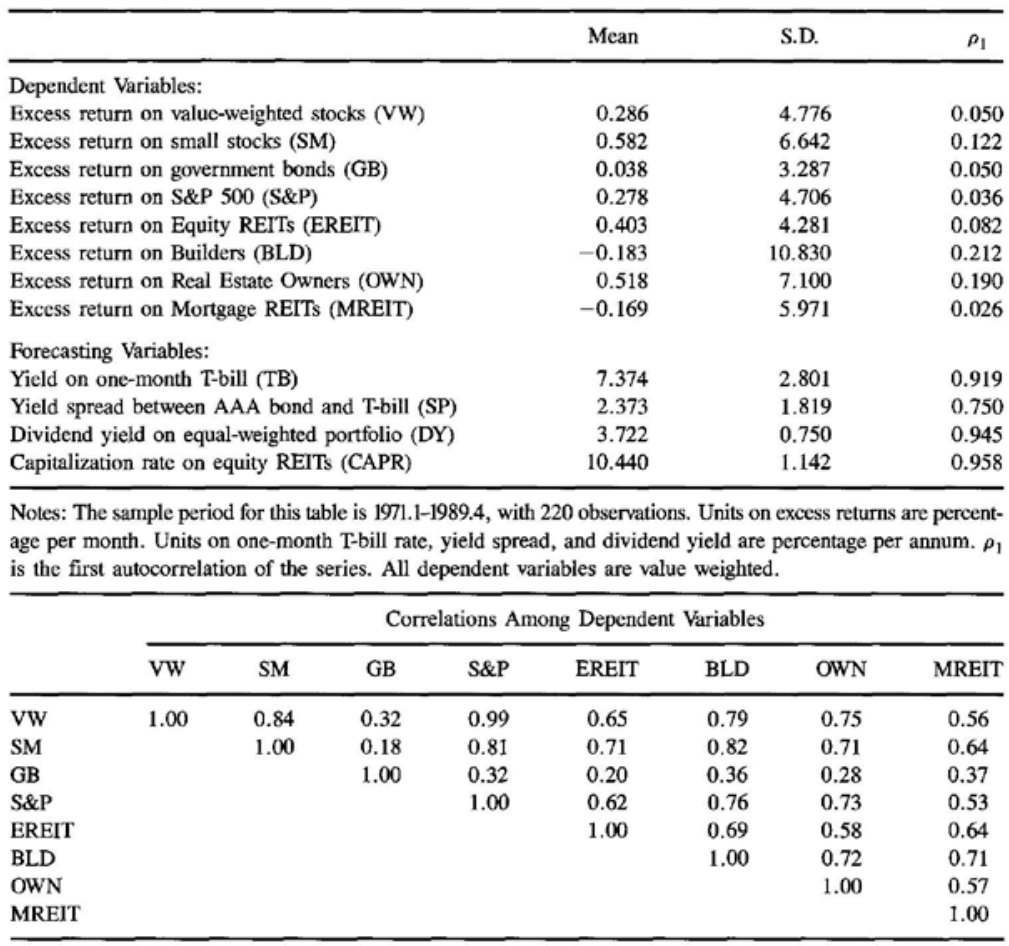

The results of regressing excess assets returns on five forecasting variables and a constant term--a January dummy, returns on Treasury bills, the spread, the dividend yield on the equally weighted market portfolio, and the cap rate are shown in table 2 . Table 2 not only reports the predictability as measured by the R-squared for the whole sample period (denoted as in-sample prediction) but it also reports the predictability as well as the variation associated with that predictability for the ten-year rolling regressions which are used for forming out-of-sample excess return forecasts. Table 2 indicates that although returns on small stocks have the largest in-sample predictability, a larger component of the excess return on builders is predictable relative to all other real estate firm classifications as well as non-real estate assets in terms of out-of-sample prediction. In particular, the five forecasting variables account for approximately $13.6 \%$ of the variation in monthly excess returns on builders. The out-of-sample predictability on returns for owners and mortgage REITs are $10.3 \%$ and $10.9 \%$ respectively which are greater than the return predictability for all other asset classes except builders and small stocks. In contrast, the returns on equity REITs and large stocks have similar out-of-sample predictability although more of the in-sample return variation of the former asset can be accounted for relative to the latter asset class. ${ }^{6}$ In summary, the degree to which the excess returns on

\footnotetext{
${ }^{6}$ The predictability for equity REITs relative to small stocks differ somewhat from Liu and Mei (1991) since our study uses value weighted returns for real estate while the previous study employs equally weighted real estate returns. We also use an additional year of real estate returns with the data starting in January 1971. The Liu and Mei (1991) study in contrast, uses data beginning in January 1972.
} 


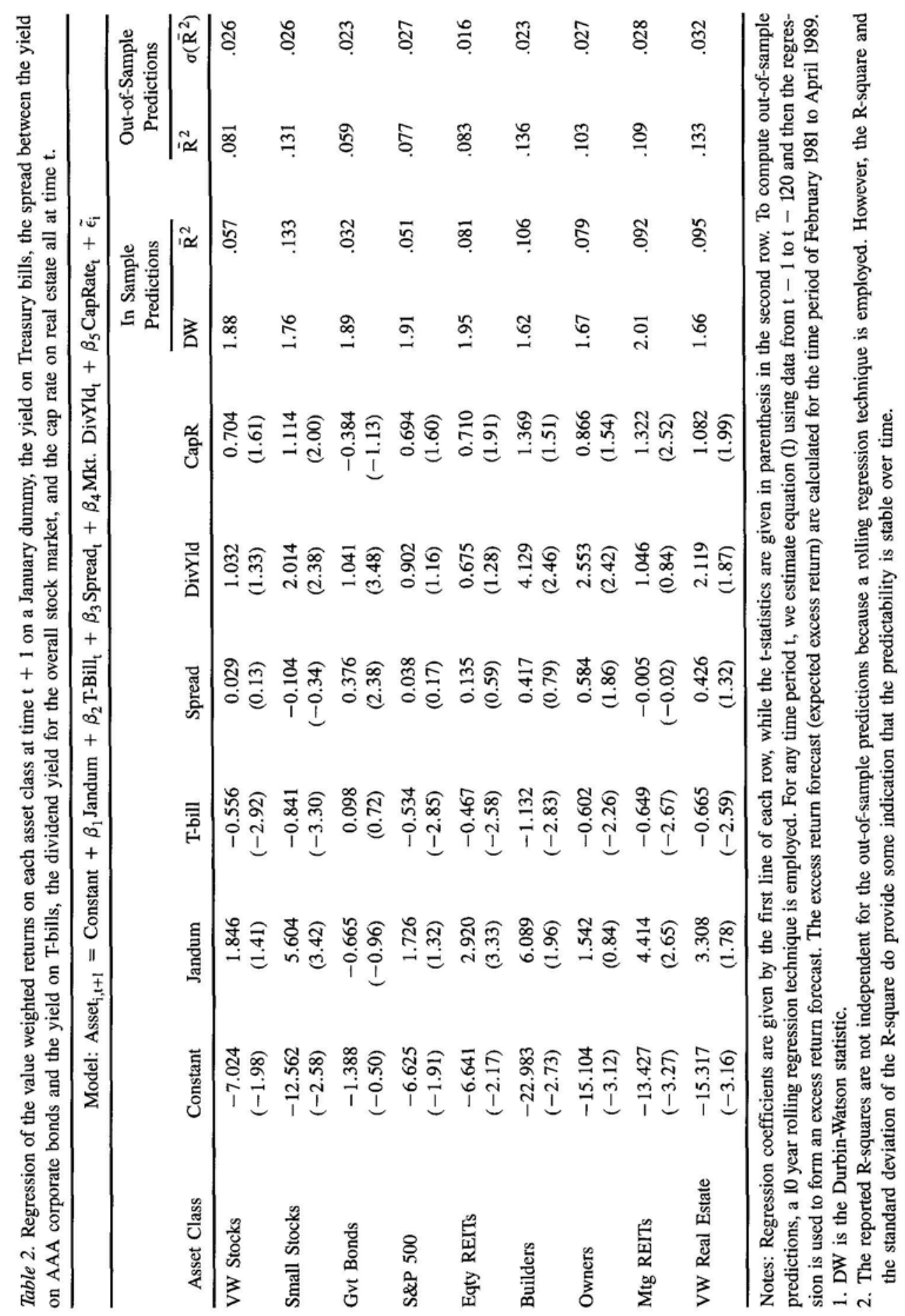

stocks, bonds, and the various real estate categories are predictable is consistent with the previous studies of Campbell and Hamao (1991), Harvey (1989), Gyourko and Keim (1991) and Liu and Mei (1991), among others. The standard deviation of the R-square in the last column of table 2, which is not looked at or reported in previous studies, also reveals that the degree of predictability remains relatively stable over time for all asset classes which suggests that any 
successful market timing strategy will tend to remain effective over time. Moreover, table 2 reveals that the predictability associated with the return on builders is more stationary relative to small stocks as well as other asset categories. The only exception to this is equity REITs which have the greatest amount of stability of out-of-sample predictions. When the within sample predictability is compared to the out-of-sample predictability, it is readily apparent that the numbers are similar for each asset class with the predictability of excess returns slightly stronger for the out-of-sample data set which is another indication of the strength of the predictability. The most distinguishing feature of table 2 therefore, is that the return on builders are not only higher relative to small stocks in terms of the level of out-of-sample predictability but also more stability is associated with this predictability. More importantly, the builders portfolio is comprised primarily of large cap stocks. In contrast to this, the equity and mortgage REIT portfolios are small stock portfolios. However, Liu and Mei (1992) have shown that REITs differ from small cap stocks in that most of the variation in unexpected real estate returns is due to cash flow fluctuations while movements in discount rate account for most of the fluctuations in the unexpected portion of small cap returns. This therefore raises the question of whether real estate stocks will differ from small stocks with respect to market timing given that they are similar with respect to predictability but differ in terms of what accounts for the variations in their respective unexpected returns.

A visual impression of the results in table 2 is given in figure 1 . Figure 1 plots the conditional expected (predicted) excess return $\left[\boldsymbol{E}_{\boldsymbol{t}}\left(\tilde{\boldsymbol{r}}_{\boldsymbol{i}, \boldsymbol{t}+\mathbf{1}}\right)\right]$ for Standard \& Poor's 500, equity REITs, homebuilders, property owners, and mortgage REITs. The graph shows that the expected excess returns vary over time, sometimes taking positive values and sometimes taking negative values as expected. The most interesting aspect of figure 1 is that the monthly predictable excess returns for homebuilders can reach a maximum of $18 \%$. The high expected return in the beginning of each year reflects the well-documented January Effect for stocks and equity REITs (see, for instance, Keim (1983), and Liu and Mei (1992)). In terms of volatility in the expected excess returns, the biggest volatility in $\left[\boldsymbol{E}_{\boldsymbol{t}}\left(\tilde{\boldsymbol{r}}_{\boldsymbol{i}, \boldsymbol{t}+\mathbf{1}}\right)\right]$ is associated with homebuilders as well. The predictability in the expected excess returns which we document could come from two major sources. First, it could just reflect rational pricing in an efficient market under different business conditions. Second, it could come from market inefficiency as a result of investor overreaction (for instance, see DeBondt and Thaler (1988)). In any case, the huge variation in expected excess returns creates market timing opportunities for long term investors. 


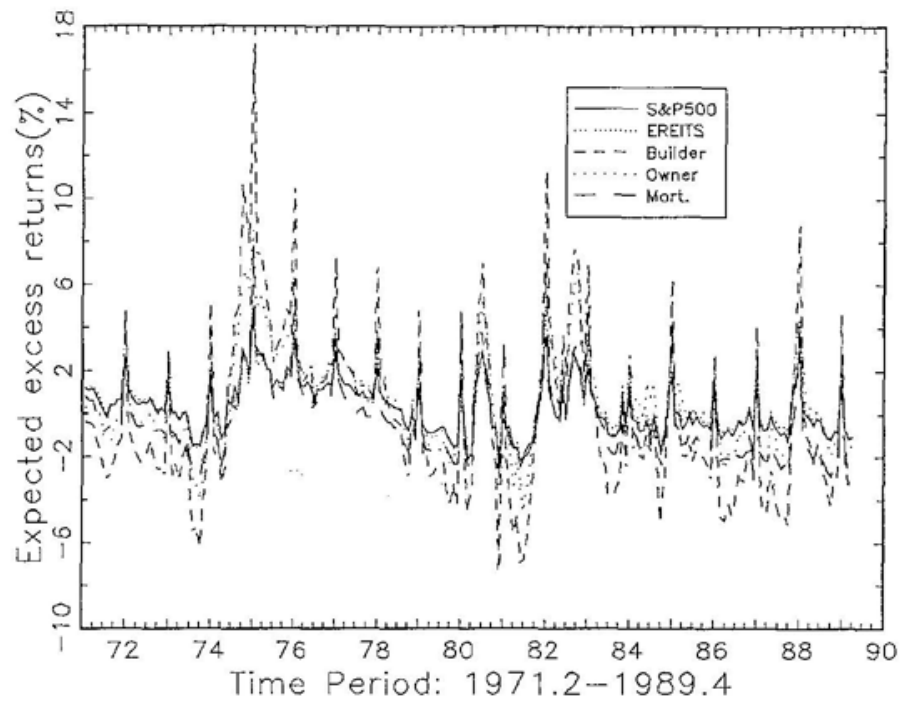

Figure 1. Conditional risk premium on real estate assets.

Given our findings in table 2 that all assets to some degree are predictable and that this predictability is relatively stationary over time, we now turn to the central focus of this paper, namely to what extent can we exploit the degree of predictability and the stability of this predictability in asset returns to obtain superior investment returns through market timing. To evaluate the success or failure of market timing performance, we construct three trading strategies. More specifically, we form two active portfolios: a Long (+) portfolio and a Long (+) and Short (-) portfolio as well as a passive buy and hold portfolio. These portfolios are explained in greater detail subsequently. The passive buy and hold portfolio is used as our benchmark for comparing whether superior returns are possible. The unadjusted and risk adjusted excess returns from each asset class are compared against each other as well as the S\&P 500 benchmark over various trading strategies to determine not only the relative asset investment performance but also the consistency of that performance. In undertaking this analysis, we assume that the ex ante expected excess returns on its investments over the holding period is all that a risk neutral and value maximizing investor should care about. Thus, a rational investor should attempt to increase his real estate investments when the future expected excess returns on real estate are positive. An investor will choose to close or reduce his real estate investment position when expected excess returns are negative, since a negative expected excess return implies taking a gamble with unfavorable odds.

Table 3 reports the mean excess returns unadjusted for risk for the passive Buy and Hold portfolio and the two active portfolio strategies for large cap stocks, small cap stocks, government bonds, the S\&P 500 benchmark portfolio as well as four different categories of real estate firms while table 4 reports the same information adjusted for risk using the capital asset pricing model. The first row with respect to each strategy represents the mean excess return, 
the second row represents the standard deviation of that excess return while the $T$ value associated with the mean excess return is located in the third row for both table 3 and table 4 . Both tables reveal that the Long $(+)$ and Short $(-)$ portfolio and also the Long $(+)$ portfolio outperform the passive Buy and Hold portfolio with respect to a value weighted portfolio consisting of all types of real estate firms with the former actively managed strategy doing slightly better than the latter active strategy. Similar results also obtain for an equally weighted portfolio of various value weighted real estate groupings. The T values in table 3 and table 4 also reveal that the relative portfolio performance arising from either active trading strategy is either statistically significant.

Table 3. Mean portfolio excess returns based on out-of-sample prediction excess returns are not adjusted for risk.

\begin{tabular}{|c|c|c|c|}
\hline & \multicolumn{3}{|c|}{ Trading Strategies } \\
\hline & Buy and Hold & Long $(+)$ and Short $(-)$ & Long $(+)$ \\
\hline \multirow[t]{3}{*}{ VW Stocks } & 0.520 & 0.169 & 0.344 \\
\hline & $(4.83)$ & $(4.86)$ & $(2.64)$ \\
\hline & {$[1.07]$} & {$[0.35]$} & [1.30] \\
\hline \multirow[t]{3}{*}{ Small Stocks } & 0.452 & 0.778 & 0.615 \\
\hline & $(5.64)$ & $(5.60)$ & (3.19) \\
\hline & {$[0.80]$} & [1.38] & [1.92] \\
\hline \multirow[t]{3}{*}{ Government Bonds } & 0.427 & 0.229 & 0.328 \\
\hline & $(3.84)$ & $(3.86)$ & $(1.91)$ \\
\hline & [1.11] & [0.59] & {$[1.71]$} \\
\hline \multirow[t]{3}{*}{ S\&P 500} & 0.551 & 0.172 & 0.362 \\
\hline & $(4.87)$ & $(4.90)$ & $(2.72)$ \\
\hline & [1.13] & {$[0.35]$} & {$[1.32]$} \\
\hline \multirow[t]{3}{*}{ Equity REITs } & 0.469 & 0.951 & 0.710 \\
\hline & $(3.19)$ & $(3.08)$ & $(2.18)$ \\
\hline & [1.46] & [3.07] & [3.24] \\
\hline \multirow[t]{3}{*}{ Builders } & -0.109 & 1.850 & 0.870 \\
\hline & $(9.99)$ & $(9.82)$ & $(5.79)$ \\
\hline & {$[-0.11]$} & [1.87] & [1.49] \\
\hline \multirow[t]{3}{*}{ Owners } & 1.140 & 0.780 & 0.961 \\
\hline & $(5.89)$ & $(5.95)$ & $(3.30)$ \\
\hline & [1.93] & [1.30] & {$[2.90]$} \\
\hline \multirow[t]{3}{*}{ Mortgage REITs } & -0.098 & 0.716 & 0.309 \\
\hline & $(3.78)$ & $(3.71)$ & $(2.42)$ \\
\hline & {$[-0.26]$} & [1.92] & {$[1.27]$} \\
\hline \multirow[t]{3}{*}{ VW Real Estate } & 0.710 & 0.766 & 0.738 \\
\hline & $(5.23)$ & $(5.22)$ & $(3.07)$ \\
\hline & [1.35] & {$[1.46]$} & {$[2.40]$} \\
\hline \multirow[t]{3}{*}{$E W$ of $V W$ Real Estate } & 0.351 & 0.949 & 0.650 \\
\hline & $(4.95)$ & $(4.87)$ & $(2.98)$ \\
\hline & {$[0.71]$} & [1.94] & {$[2.17]$} \\
\hline
\end{tabular}

Note: The first row for each asset given a particular strategy represents the mean excess return, the second row represents the standard deviation of that excess return while the $T$ value associated with the mean excess return is located in the third row. All returns are value weighted except the last return series which is the equally weighted portfolio of the 4 value weighted real estate return series. 
Slightly different results are obtained when individual real estate firm categories are examined in table 3 and in table 4 . In both tables, the monthly mean excess returns for all real estate firm categories using either active trading strategy exceed those returns for the corresponding passive strategy except for the property owner portfolio in table 3. However, the mean excess returns associated with the active strategies are not necessarily significant (e.g., statistically greater than zero). Homebuilding stocks have the highest mean excess return from either an unadjusted or risk adjusted perspective when a Long and Short trading strategy is implemented. More specifically, the mean risk adjusted excess return for homebuilders exceeds 2.2\% per month for the Long (+) and Short (-) strategy. In contrast, the passive buy and hold homebuilder portfolio experiences negative mean risk adjusted excess returns of $-1.03 \%$. Builder returns for both of these strategies are statistically significant from zero. The riskadjusted returns from holding a long position in the homebuilder portfolio however does not differ statistically from zero. When a long strategy is chosen, the property owner portfolio has the largest mean excess returns of all asset classes. Surprisingly, the active trading profits for all real estate categories except mortgage REITs exceed the corresponding profits for small stocks even though table 2 reveals that the in-sample predictability and out-of-sample predictability of small stocks exceed all real estate classes (with the exception of builders for the out-of-sample predictability scenario). This condition holds for both the case of unadjusted and risk-adjusted returns. Although the returns from implementing an active trading strategy for small stocks is larger than that for mortgage REITs in general, it is not necessarily true that they are statistically different from a zero return. What this suggests is that even though one could argue that real estate stocks are small stocks or behave similarly to small stocks, real estate stocks outperform small stocks with respect to returns using a market timing scheme in general. Moreover, all real estate categories exhibit higher returns from an active trading strategy relative to either large cap stocks or government bonds. However table 4 also reveals that a higher amount of volatility exists, the higher the level of mean excess returns which is not surprising. Thus, homebuilders have the highest volatility while equity REITs have the lowest fluctuations around their respective mean excess returns of the four real estate portfolios examined.

In contrast to real estate firms, an inspection of the nonreal estate asset categories reveals that the two active trading strategies do not necessarily outperform a passive buy and hold strategy. This is the case for large cap stocks and government bonds when excess returns are not riskadjusted. However, the active trading strategies do outperform a buy and hold strategy for large stocks but not for bonds when returns are risk-adjusted.

How well do the various asset classes do relative to the S\&P 500 benchmark? Although table 3 indicates that the evidence is mixed when the unadjusted mean portfolio excess return for each asset class is compared to the S\&P 500, table 4 clearly shows that all types of real estate firms outperform the S\&P 500 in terms of both active trading strategies when returns are adjusted 
for risk. Of the nonreal estate assets, table 4 reveals that only small cap stocks consistently beat the market (S\&P 500) when either active trading strategy is used which is not surprising given the relatively high level of predictability associated with small cap stocks. However, the performance of small cap stocks is less spectacular to that of the various real estate portfolios with the exception of mortgage REITs.

Table 4. Mean risk-adjusted portfolio excess returns based on out-of-sample prediction.

\begin{tabular}{|c|c|c|c|}
\hline & \multicolumn{3}{|c|}{ Trading Strategies } \\
\hline & Buy and Hold & Long $(+)$ and Short $(-)$ & Long (+) \\
\hline \multirow[t]{3}{*}{ VW Stocks } & -0.025 & 0.385 & 0.180 \\
\hline & $(0.30)$ & $(4.46)$ & $(2.20)$ \\
\hline & {$[-0.84]$} & {$[0.86]$} & {$[0.81]$} \\
\hline \multirow[t]{3}{*}{ Small Stocks } & -0.099 & 0.954 & 0.428 \\
\hline & (2.84) & $(5.38)$ & $(2.73)$ \\
\hline & {$[-0.35]$} & {$[1.76]$} & [1.56] \\
\hline \multirow[t]{3}{*}{ Government Bonds } & 0.270 & 0.257 & 0.263 \\
\hline & $(3.58)$ & $(3.85)$ & $(1.82)$ \\
\hline & {$[0.75]$} & [0.66] & [1.44] \\
\hline \multirow[t]{3}{*}{ S\&P 500} & $* * * *$ & 0.383 & 0.191 \\
\hline & $* * * *$ & $(4.54)$ & $(2.27)$ \\
\hline & $* * * *$ & {$[0.84]$} & {$[0.84]$} \\
\hline \multirow[t]{3}{*}{ Equity REITs } & 0.206 & 0.993 & 0.599 \\
\hline & $(2.18)$ & $(3.06)$ & (1.95) \\
\hline & {$[0.94]$} & [3.23] & [3.07] \\
\hline \multirow[t]{3}{*}{ Builders } & -1.030 & 2.200 & 0.585 \\
\hline & $(5.83)$ & $(9.33)$ & $(5.22)$ \\
\hline & {$[-1.75]$} & {$[2.34]$} & [1.12] \\
\hline \multirow[t]{3}{*}{ Owners } & 0.640 & 0.967 & 0.803 \\
\hline & (3.87) & $(5.72)$ & (2.99) \\
\hline & {$[1.64]$} & {$[1.68]$} & {$[2.68]$} \\
\hline \multirow[t]{3}{*}{ Mortgage REITs } & -0.353 & 0.775 & 0.211 \\
\hline & (3.03) & (3.67) & $(2.26)$ \\
\hline & {$[-1.16]$} & {$[2.10]$} & [0.93] \\
\hline \multirow[t]{3}{*}{$V W$ Real Estate } & 0.203 & 0.956 & 0.580 \\
\hline & $(2.70)$ & $(4.95)$ & $(2.73)$ \\
\hline & {$[0.75]$} & [1.92] & {$[2.12]$} \\
\hline \multirow[t]{3}{*}{ EW of VW Real Estate } & -0.133 & 0.090 & 0.478 \\
\hline & (2.49) & $(4.71)$ & $(2.56)$ \\
\hline & {$[-0.53]$} & {$[2.30]$} & [1.86] \\
\hline
\end{tabular}

Note: The first row for each asset given a particular strategy represents the mean excess return, the second row represents the standard deviation of that excess return while the $T$ value associated with the mean excess return is located in the third row. All returns are value weighted except the last return series which is the equally weighted portfolio of the 4 value weighted real estate return series.

When table 3 and table 4 are examined in terms of portfolio risk, the distinguishing conclusion from these tables is that the value weighted portfolio consisting of all real estate groups has a total risk level similar to that of the nonreal estate asset groups yet it has higher mean excess 
returns in general. The only exception to this is the comparison to small stocks using a Long and Short positions when excess returns are not risk-adjusted. The level of risk for each individual real estate portfolio is also comparable to that of other assets with the possible exception of homebuilders in table 4 whose total risk is higher. However, it is unclear whether the individual real estate groupings in contrast to the value weighted real estate portfolio necessarily have higher relative mean excess returns. This is particularly true for mortgage REITs. This suggests that the covariances among the real estate types are moderate at best which is evidenced in table 1 and therefore it pays to diversify on an intra-real estate basis in order to maximize profits from an active trading strategy.

The evidence thus far appears to indicate that as the level of predictability increases for an asset class, a higher mean excess realm is associated with an active trading strategy although this tendency is not perfectly monotonic. To determine the strength of this relationship from a statistical perspective, the predictability of excess returns as measured by the out-of-sample Rsquared in table 2 is correlated against the mean excess returns in table 3 (unadjusted for risk) and table 4 (adjusted for risk) with the correlation results reported in table 5 . Table 5 shows that the level of predictability is positively correlated to the level of mean excess returns for both active trading strategies with relatively higher correlations existing for the Long and Short scenario. In particular, the mean excess returns using a Long (+) and Short (-) strategy has a .71 cross-sectional correlation while the Long (+) strategy has a .40 to .58 cross-sectional correlation with the level of out-of-sample predictability. Not surprisingly, the passive buy and hold strategy is not correlated with the level of predictability for the various asset groups. One plausible reason why the results are not stronger is that only a few asset classes are explored in terms of predictability and market timing.

Table 5. Cross-sectional correlation of out-of-sample predictability with mean excess returns. Returns are value weighted.

\begin{tabular}{lcc}
\hline \multicolumn{1}{c}{ Trading Strategy } & $\begin{array}{c}\text { Mean Excess Returns } \\
\text { Unadjusted for Risk }\end{array}$ & $\begin{array}{c}\text { Mean Excess Returns } \\
\text { Adjusted for Risk }\end{array}$ \\
\hline Buy and Hold & -.20 & -.48 \\
Long (+) and Short $(-)$ & .71 & .71 \\
Long (+) & .58 & .40 \\
\hline Notes: & & \\
1. The out-of-sample predictability is the out-of-sample R-squared column in table 2. \\
2. The mean excess returns unadjusted for risk is obtained from table 3. \\
3. The mean excess returns adjusted for risk using the CAPM is taken from table 4.
\end{tabular}

A key question of interest to investment managers is to what extent does portfolio wealth increase as the result of these active trading strategies? What is the actual magnitude of trading profits relative to a buy and hold strategy involving that particular asset or alternatively the S\&P 500 ? Do cumulative returns from the market timing of a particular portfolio exceed those from market timing the S\&P 500? The answers to these questions are reported in table 6. All real 
Table 6. Cumulative excess trading profits unadjusted for risk. All returns are value weighted 1981.2 to 1989.12.

\begin{tabular}{|c|c|c|c|c|c|c|}
\hline & $\begin{array}{l}\text { Initial } \\
\text { Wealth }\end{array}$ & $\begin{array}{l}\text { Terminal } \\
\text { Wealth }\end{array}$ & $\begin{array}{l}\text { Final } \\
\text { Profit }\end{array}$ & $\begin{array}{l}\text { Relative } \\
\text { Profit1 }\end{array}$ & $\begin{array}{l}\text { Relative } \\
\text { Profit2 }\end{array}$ & $\begin{array}{l}\text { Relative } \\
\text { Profit3 }\end{array}$ \\
\hline \multicolumn{7}{|l|}{ I. Buy and Hold Strategy } \\
\hline S\&P 500 & 100.00 & 151.20 & 51.20 & 0.00 & 0.00 & $* * *$ \\
\hline $\begin{array}{l}\text { Value Weighted Stocks } \\
\text { Small Stocks } \\
\text { Government Bonds }\end{array}$ & $\begin{array}{l}100.00 \\
100.00 \\
100.00\end{array}$ & $\begin{array}{l}147.20 \\
131.50 \\
150.20\end{array}$ & $\begin{array}{l}47.20 \\
31.50 \\
50.20\end{array}$ & $\begin{array}{r}-4.00 \\
-19.70 \\
-1.00\end{array}$ & $\begin{array}{r}-4.00 \\
-19.70 \\
-1.00\end{array}$ & $\begin{array}{l}* * * \\
* * * \\
* * *\end{array}$ \\
\hline $\begin{array}{l}\text { Equity REITs (EREIT) } \\
\text { Homebuilders } \\
\text { Property Owners } \\
\text { Mortgage REITs (MREIT) }\end{array}$ & $\begin{array}{l}100.00 \\
100.00 \\
100.00 \\
100.00\end{array}$ & $\begin{array}{r}150.90 \\
52.27 \\
254.20 \\
85.82\end{array}$ & $\begin{array}{r}50.90 \\
-47.73 \\
154.20 \\
-14.18\end{array}$ & $\begin{array}{r}-0.30 \\
-98.93 \\
103.00 \\
-65.38\end{array}$ & $\begin{array}{r}-0.30 \\
-98.93 \\
103.00 \\
-65.38\end{array}$ & $\begin{array}{l}* * * \\
* * * \\
* * * \\
* * *\end{array}$ \\
\hline $\begin{array}{l}\text { VW Real Estate } \\
\text { EW of VW Real Estate }\end{array}$ & $\begin{array}{l}100.00 \\
100.00\end{array}$ & $\begin{array}{l}173.00 \\
124.20\end{array}$ & $\begin{array}{l}73.00 \\
24.20\end{array}$ & $\begin{array}{r}21.80 \\
-27.00\end{array}$ & $\begin{array}{r}21.80 \\
-27.00\end{array}$ & $\begin{array}{l}* * * \\
* * *\end{array}$ \\
\hline \multicolumn{7}{|c|}{ II. Long (+) and Short (-) Strategy } \\
\hline S\&P 500 & 100.00 & 104.70 & 4.70 & -46.50 & -0.01 & -46.50 \\
\hline $\begin{array}{l}\text { Value Weighted Stocks } \\
\text { Smail Stocks } \\
\text { Government Bonds }\end{array}$ & $\begin{array}{l}100.00 \\
100.00 \\
100.00\end{array}$ & $\begin{array}{l}104.80 \\
187.10 \\
110.50\end{array}$ & $\begin{array}{r}4.80 \\
87.10 \\
10.50\end{array}$ & $\begin{array}{r}-46.40 \\
35.90 \\
-40.70\end{array}$ & $\begin{array}{r}0.09 \\
82.39 \\
5.79\end{array}$ & $\begin{array}{r}-42.40 \\
55.60 \\
-39.70\end{array}$ \\
\hline $\begin{array}{l}\text { Equity REITs (EREIT) } \\
\text { Homebuilders } \\
\text { Property Owners } \\
\text { Mortgage REITs (MREIT) }\end{array}$ & $\begin{array}{l}100.00 \\
100.00 \\
100.00 \\
100.00\end{array}$ & $\begin{array}{l}244.40 \\
389.40 \\
178.90 \\
192.60\end{array}$ & $\begin{array}{r}144.40 \\
289.40 \\
78.90 \\
92.60\end{array}$ & $\begin{array}{r}93.20 \\
238.20 \\
27.70 \\
41.40\end{array}$ & $\begin{array}{r}139.69 \\
284.69 \\
74.19 \\
87.89\end{array}$ & $\begin{array}{r}93.50 \\
337.13 \\
-75.30 \\
106.78\end{array}$ \\
\hline $\begin{array}{l}\text { VW Real Estate } \\
\text { EW of VW Real Estate }\end{array}$ & $\begin{array}{l}100.00 \\
100.00\end{array}$ & $\begin{array}{l}184.70 \\
226.80\end{array}$ & $\begin{array}{r}84.70 \\
126.80\end{array}$ & $\begin{array}{l}33.50 \\
75.60\end{array}$ & $\begin{array}{r}79.99 \\
122.09\end{array}$ & $\begin{array}{r}11.70 \\
102.60\end{array}$ \\
\hline \multicolumn{7}{|l|}{ III. Long (+) Strategy } \\
\hline S\&P 500 & 100.00 & 136.60 & 36.60 & -14.60 & 0.00 & -14.60 \\
\hline $\begin{array}{l}\text { Value Weighted Stocks } \\
\text { Small Stocks } \\
\text { Government Bonds }\end{array}$ & $\begin{array}{l}100.00 \\
100.00 \\
100.00\end{array}$ & $\begin{array}{l}134.90 \\
175.00 \\
135.90\end{array}$ & $\begin{array}{l}34.90 \\
75.00 \\
35.90\end{array}$ & $\begin{array}{r}-16.30 \\
23.80 \\
-15.30\end{array}$ & $\begin{array}{r}-1.70 \\
38.40 \\
-0.70\end{array}$ & $\begin{array}{r}-12.30 \\
43.50 \\
-14.30\end{array}$ \\
\hline $\begin{array}{l}\text { Equity REITs (EREIT) } \\
\text { Homebuilders } \\
\text { Property Owners } \\
\text { Mortgage REITs (MREIT) }\end{array}$ & $\begin{array}{l}100.00 \\
100.00 \\
100.00 \\
100.00\end{array}$ & $\begin{array}{l}197.00 \\
199.00 \\
240.50 \\
133.90\end{array}$ & $\begin{array}{r}97.00 \\
99.00 \\
140.50 \\
33.90\end{array}$ & $\begin{array}{r}45.80 \\
47.80 \\
89.30 \\
-17.30\end{array}$ & $\begin{array}{r}60.40 \\
62.40 \\
103.90 \\
-2.70\end{array}$ & $\begin{array}{r}46.10 \\
146.73 \\
-13.70 \\
48.08\end{array}$ \\
\hline $\begin{array}{l}\text { VW Real Estate } \\
\text { EW of VW Real Estate }\end{array}$ & $\begin{array}{l}100.00 \\
100.00\end{array}$ & $\begin{array}{l}195.30 \\
181.20\end{array}$ & $\begin{array}{l}95.30 \\
81.20\end{array}$ & $\begin{array}{l}44.10 \\
30.00\end{array}$ & $\begin{array}{l}58.70 \\
44.60\end{array}$ & $\begin{array}{l}22.30 \\
57.00\end{array}$ \\
\hline
\end{tabular}

Notes:

1. Excess trading profits are calculated in excess of the t-bill rate.

2. Terminal wealth is the wealth at the end of December 1989 from a portfolio having an initial wealth of $\$ 100$ in February of 1981.

3. Final profit is calculated as the difference between the terminal wealth at the end of December 1989 and the initial wealth at February 1981.

4. Relative Profitl is calculated as the terminal wealth for an asset relative to the terminal wealth for the S\&P 500 assuming a passive buy and hold strategy for the S\&P 500 .

5. Relative Profit 2 is calculated as the terminal wealth for an asset relative to the terminal wealth for the S\&P 500 assuming that both portfolios use the same trading strategy.

6. Relative Profit 3 is calculated as the terminal wealth for an asset given an active trading strategy relative to the terminal wealth for that asset assuming a passive buy and hold strategy.

estate portfolios exhibit positive net performance relative to the three cumulative wealth benchmarks for the active trading strategies except for the Owner portfolio. These benchmarks are the final wealth levels associated with the buy and hold S\&P 500 (relative profit1), a portfolio based on an appropriate actively traded S\&P 500 portfolio strategy (relative profit2), and finally a passive portfolio consisting of that particular asset whose active strategy is the 
object of comparison (relative profit3). Starting with an initial wealth of $\$ 100$ in February of 1981, an investor would have realized a net profit of between $\$ 78-\$ 289$ from a Long $(+)$ and Short (-) strategy and between \$34-\$141 from a Long (+) strategy depending on which real estate portfolio he invested in. These net profits on real estate exceed the net profit of $\$ 51$ if the S\&P 500 were purchased and held. The only exception to this is the net profits from a long position in mortgage REITs. The relative net profits for equity REITs, builders, and mortgage REITs also exceed the compensation from simply buying and holding each of the respective real estate portfolios (see Relative Profit3). However, a buy and hold strategy results in greater trading profits relative to a long position in the real estate owner portfolio.

When the individual real estate portfolios are examined, the most impressive gains are associated with homebuilder stocks using the Long (+) and Short (-) market timing with a $\$ 238.20$ and an even greater $\$ 337.13$ net profit realized over and above a passive strategy involving purchasing the S\&P 500 and homebuilder portfolios respectively at the start of 1981 and selling the portfolios at the end of 1989. In contrast, negative profits are obtained for the property owner portfolio when either market timing strategy is compared against the passive alternative. However, the total gain for the Owner portfolio still exceeds the dollar returns achieved from the S\&P 500 using any of the three strategies examined. More specifically, a gain of $\$ 74.19$ is realized when terminal wealth from an actively managed Long (+) and Short (-) Owner portfolio is compared to final wealth from market timing the S\&P 500.

Of the nonreal estate assets included in the study, only small cap stocks post positive gains when compared to the three benchmarks. However, the magnitude of these profits are smaller relative to any of the real estate portfolios except for the Long and Short strategy for the Owner portfolio and the Long position for the mortgage REIT portfolio. Both value weighted stocks and government bonds perform poorly relative to all benchmarks having minimal to negative relative wealth.

Figures 2, 3, and 4 graphically present a more complete perspective of the cumulative wealth level (the Y-axis on each graph) from implementing a buy and hold strategy, the long and short strategy, and the long strategy respectively for the four real estate portfolios. For comparison purposes, the cumulative wealth levels corresponding to buying and holding the S\&P 500 is also included in each graph. A comparison of these figures confirm our earlier observations that homebuilders have the most spectacular increase in wealth over time, and that of the three trading strategies, the Long (+) and Short (-) strategy results in the largest wealth levels for all real estate portfolios. In contrast, a Long scheme leads to the highest wealth accumulation for the Owner group. However, figure 4 shows that over the period from the second quarter of 1986 to approximately the third quarter of 1987 and from the second to the third quarter of 
1987, a passive buy and hold S\&P 500 strategy would have outperformed the mortgage REIT and Builder portfolios respectively.

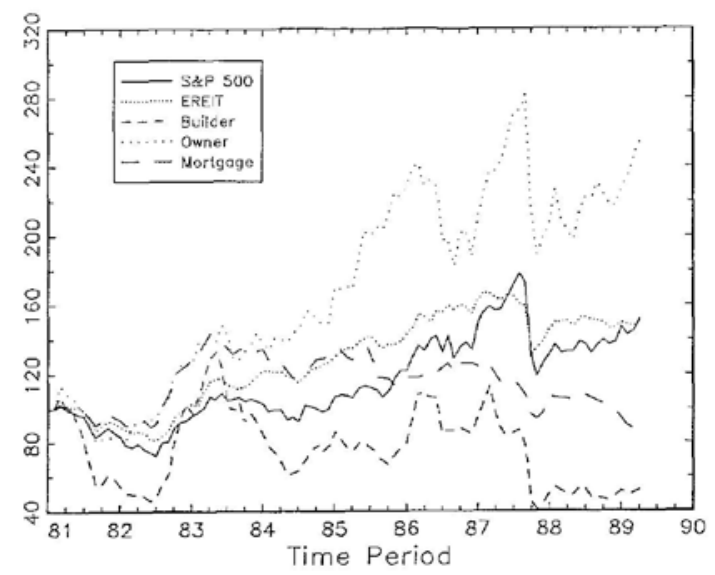

Figure 2. Cumulative return on the buy-and-hold strategy.

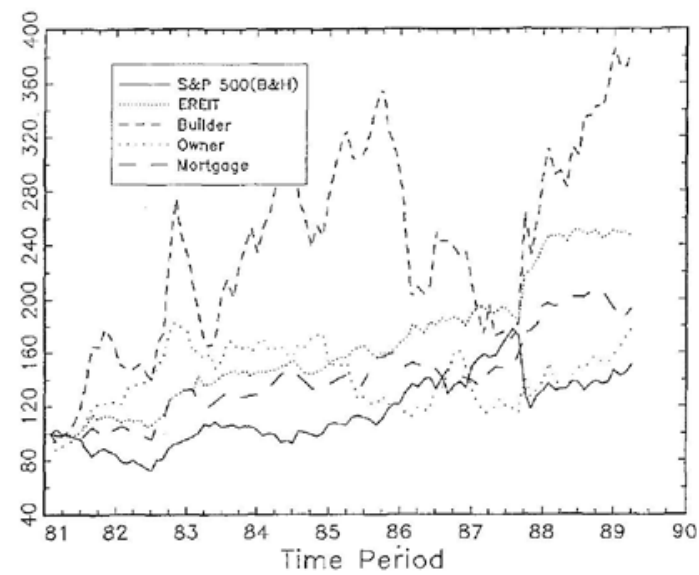

Figure 3. Cumulative excess return on the Long (+) and Short (-) strategy.

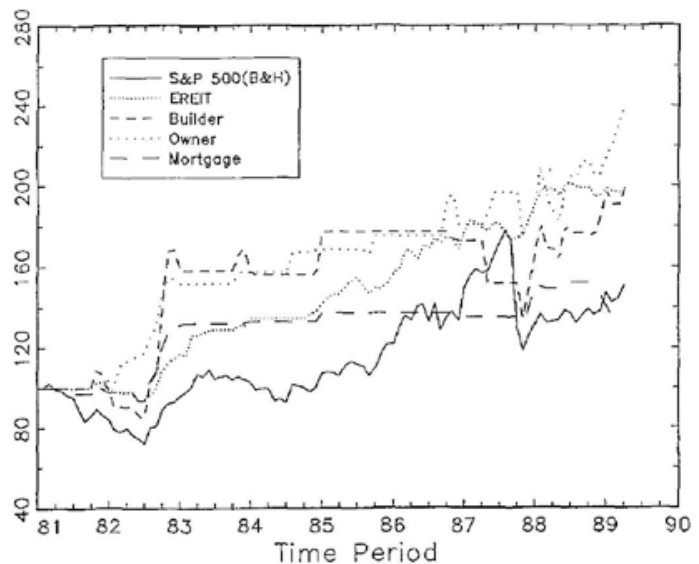

Figure 4. Cumulative excess return on the Long (+) strategy. 


\section{Summary and Conclusions}

Recent evidence suggests that all asset returns are predictable to some extent with excess returns on real estate relatively easier to forecast. This raises the issue of whether we can successfully exploit this level of predictability using various market timing strategies to realize superior performance over a buy and hold strategy. Before addressing this issue, the study of Liu and Mei (1991) is replicated using several additional value-weighted real estate categories to first determine whether their results hold over a broader range of firms. The study finds that the degree of predictability for various types of exchange traded real estate firms is similar albeit lower than the forecasting level which Liu and Mei (1991) find for an equally weighted portfolio of equity REITs. Moreover, this predictability remains relatively stationary over time for all asset classes which suggests that any successful market timing scheme will tend to remain effective over time. To evaluate the success of market timing performance, 2 active trading tactics are constructed together with a passive buy and hold strategy. Our main finding is that a value-weighted portfolio consisting of various types of exchange traded real estate firms using either active trading strategy outperforms a passive scheme from either an unadjusted or risk adjusted return perspective. Moreover, real estate stocks not only have higher average risk-adjusted returns but also larger trading profits with few exceptions even though small stocks have the highest degree of out-of-sample predictability. What is even more interesting is that the builder group, which consists primarily of large cap stocks, has the highest mean excess return from either an unadjusted or risk adjusted perspective when either active trading method is chosen with a phenomenal $2.3 \%$ excess return per month on average using the Long (+) and Short (-) strategy. In contrast to real estate firms, the mean excess returns associated with the two active trading strategies tested do not necessarily outperform a passive buy and hold scheme for large-cap stocks and government bonds. In summary, moderate evidence is found to support the proposition that we can successfully exploit the level of predictability associated with excess asset returns using various active market timing strategies to realize superior performance over a buy and hold strategy.

\section{Acknowledgments}

We wish to thank Doug Herold and Wayne Ferson for providing data on real estate cap rates and business condition factors respectively to us. We also wish to thank John Campbell for helpful comments and Bin Gao for excellent research assistance. 


\section{Appendix}

Elaboration of the Asset Pricing Framework and Estimation Procedure ${ }^{7}$

The asset pricing framework used in this study follows that of Liu and Mei (1991) and assumes that the following $\mathrm{K}$-factor model generates asset returns:

$$
\tilde{r}_{i, t+1}=E_{t}\left[\tilde{r}_{i, t+1}\right]+\sum_{k=1}^{K} \beta_{i k} \tilde{f}_{k, t+1}+\widetilde{\in}_{i, t+1}
$$

where $\tilde{\boldsymbol{r}}_{\boldsymbol{i}, \boldsymbol{t + 1}}$ is the excess return on asset $\boldsymbol{i}$ held from time $\boldsymbol{t}$ to time $\boldsymbol{t}+\mathbf{1}, \boldsymbol{E}_{\boldsymbol{t}}\left[\tilde{\boldsymbol{r}}_{\boldsymbol{i}, \boldsymbol{t}+\mathbf{1}}\right]$ is the conditional expected excess return on asset $i$, conditional on information known to market participants at the end of time period $\boldsymbol{t}, \boldsymbol{E}_{t}\left[\boldsymbol{t}_{k, t+1}\right]=\mathbf{0}$ and $\boldsymbol{E}_{t}\left[\widetilde{\epsilon}_{i, t+1}\right]=\mathbf{0}$. The conditional expected excess return, $\boldsymbol{E}_{\boldsymbol{t}}\left[\tilde{\boldsymbol{r}}_{\boldsymbol{i}, \boldsymbol{t}+\mathbf{1}}\right]$, can vary through time in the current model although the framework assumes that the beta coefficients are stationary. Since $\boldsymbol{E}_{\boldsymbol{t}}\left[\tilde{\boldsymbol{r}}_{\boldsymbol{i}, \boldsymbol{t}+\mathbf{1}}\right]$ is not restricted to be constant, we need to consider both the closeness of beta(s) and the comovement of $\boldsymbol{E}_{\boldsymbol{t}}\left[\tilde{\boldsymbol{r}}_{\boldsymbol{i}, \boldsymbol{t + 1}}\right]$ through time in analyzing the co-movement of excess returns on two or more assets unless the following linear pricing relationship holds:

$$
E_{t}\left[\tilde{\boldsymbol{r}}_{i, t+1}\right]=\sum_{k=1}^{K} \beta_{i k} \tilde{\lambda}_{k t}
$$

where $\lambda_{\boldsymbol{k} t}$ is the "market price of risk" for the $\boldsymbol{k}^{\prime}$ th factor at time $\boldsymbol{t}$ and is equivalent to

$$
\lambda_{k t}=\sum_{n=1}^{L} \theta_{k n} X_{n t}
$$

if the information set at time $\boldsymbol{t}$ consists of a vector of $\boldsymbol{L}$ forecasting variables $\boldsymbol{X}_{\boldsymbol{n}}, \boldsymbol{n}=\mathbf{1} \ldots \boldsymbol{L}$ (where $\boldsymbol{X}_{1 t}$ is a constant) and that conditional expectations are a linear function of these variables. Substitution of (A.3) into (A.2) therefore results in:

$$
E_{t}\left[\tilde{r}_{i, t+1}\right]=\sum_{k=1}^{K} \beta_{i k} \sum_{n=1}^{L} \theta_{k n} X_{n t}=\sum_{n=1}^{L} \alpha_{i n} X_{n t}
$$

A comparison of equations (A.3) and (A.4) reveals that the model puts the following constraints on the coefficients of equation (A.4)

\footnotetext{
${ }^{7}$ This section is taken from Liu and Mei (1991).
} 


$$
\alpha_{i j}=\sum_{k=1}^{K} \beta_{i k} \theta_{k j}
$$

where $\boldsymbol{\beta}_{\boldsymbol{i} \boldsymbol{k}}$, and $\boldsymbol{\theta}_{\boldsymbol{k} \boldsymbol{j}}$ are free parameters. Although the $\left(\boldsymbol{\alpha}_{\boldsymbol{i} j}\right)$ matrix should have a rank of $\mathrm{P}$, where $P$ is defined as $P=\min (N, L)$, equation $A .5$ restricts the rank of this matrix to be $K$ where $\mathrm{K}<\mathrm{E}$ To test whether the restriction in equation $\mathrm{A} .5$ holds, we first renormalize the model by setting the factor loadings of the first $\mathrm{K}$ assets as follows: $\boldsymbol{\beta}_{\boldsymbol{i}}=\mathbf{1}$ (if $\boldsymbol{j}=\boldsymbol{i}$ ) and $\boldsymbol{\beta}_{\boldsymbol{i j}}=\mathbf{0}$ (if $\boldsymbol{j} \neq \boldsymbol{i})$ for $\mathbf{1} \leq \boldsymbol{i} \leq \boldsymbol{K}$. Next, we partition the excess return matrix $\boldsymbol{R}=\left(\boldsymbol{R}_{\mathbf{1}}, \boldsymbol{R}_{\mathbf{2}}\right)$, where $\boldsymbol{R}_{\mathbf{1}}$ is a $\mathrm{T} \times \mathrm{K}$ matrix of excess returns of the first K assets and $\boldsymbol{R}_{\mathbf{2}}$ is a $\mathrm{T} \times(\mathrm{N}-\mathrm{K})$ matrix of excess returns on the rest of the assets. Using equations (A.4) and (A.5), we can derive the following regression system

$$
\begin{aligned}
& R_{1}=X \theta+\mu_{1} \\
& R_{2}=X \alpha+\mu_{2}
\end{aligned}
$$

where $\boldsymbol{X}$ is a T $\times \mathrm{L}$ matrix of the forecasting variables, $\boldsymbol{\theta}$ is a matrix of $\boldsymbol{\theta}_{\boldsymbol{i} j}$ and $\boldsymbol{\alpha}$ is a matrix of $\boldsymbol{\alpha}_{\boldsymbol{i}}$ If the linear pricing relationship in equation A.2 holds, the rank restriction implies that the data should not be able to reject the null hypothesis $\mathrm{H}_{0}: \boldsymbol{\alpha}=\boldsymbol{\theta} \boldsymbol{B}$, where $\boldsymbol{B}$ is a matrix of $\boldsymbol{\beta}_{i j}$ elements.

To estimate (A.6) we first construct a $N \times L$ sample mean matrix: $\boldsymbol{G}_{T}=\boldsymbol{U}^{\prime} \boldsymbol{X} / \boldsymbol{T}$ where $\boldsymbol{E}\left(\boldsymbol{U}^{\prime} \boldsymbol{X}\right)=\mathbf{0}$ because the error term in system (A.6) has conditional mean zero given the instruments $\mathbf{X}$ from equation (A.4). Next, we stack the column vector on top of each other to obtain a $\mathrm{NL} \times 1$ vector of $\mathbf{g}_{\mathrm{T}}$. A two-step algorithm is then used to find an optimal solution for the quadratic form, $\boldsymbol{g}_{\dot{T}} \boldsymbol{W}^{-\mathbf{1}} \boldsymbol{g}_{T}$, by minimizing over the parameter space of $(\boldsymbol{\theta}, \boldsymbol{\alpha})$. In the first step, the identity matrix is used as the weighting matrix W. After obtaining the initial solution of $\boldsymbol{\theta}_{\mathbf{0}}$ and $\boldsymbol{\alpha}_{\mathbf{0}}$ We next calculate the residuals $\boldsymbol{\mu}_{1}$ and $\boldsymbol{\mu}_{2}$ from the system of equations in (A.6) and construct the following weighting matrix:

$$
W=\frac{1}{T} \sum_{t}\left(u_{t} u_{t}^{\prime}\right) \otimes\left(Z_{t} Z_{t}^{\prime}\right),
$$

where $\otimes$ is the Kronecker product. Next, we use the weighting matrix in (A.7) to resolve the optimization problem of minimizing $\boldsymbol{g}_{\tilde{T}} \boldsymbol{W}^{-\mathbf{1}} \boldsymbol{g}_{\boldsymbol{T}}$ over the choice of $(\boldsymbol{\theta}, \boldsymbol{\alpha})$. When the model is correctly specified (e.g., under the null hypothesis), $\boldsymbol{T} \boldsymbol{g}_{\dot{T}} \boldsymbol{W}^{\mathbf{- 1}} \boldsymbol{g}_{\boldsymbol{T}}$, is asymptotically chi-square distributed, with the degrees of freedom equal to the difference between the number of orthogonality conditions and the number of parameters estimated: $N \times L-[K \times 1+(N-K) \times K]$ $=(\mathrm{N}-\mathrm{K})(\mathrm{L}-\mathrm{K})$, where $\mathrm{N}$ is the number of assets studied, $\mathrm{K}$ is the number of factor loadings, and $L$ is the number of forecasting variables. After obtaining the weighted sum of squared residuals, 
we perform a chi-square test to determine if the data rejects the restricted regression system (A.6).

\section{References}

Campbell, John Y. "Stock Returns and the Term Structure," Journal of Financial Economics, 18 (1987), 373-399.

Campbell, John Y. "A Variance Decomposition of Stock Returns," Economic Journal, 101 (1991), 157-179.

Campbell, John Y., and Jianping Mei. Where Do Betas Come From? Asset Pricing Dynamics and the Sources of Systematic Risk, New York University Working Paper (1991).

Campbell, John Y., and Yasushi Hamao. "Predictable Stock Returns in the United States and Japan: A Study of Long-Term Capital Market Integration" Journal of Finance, forthcoming.

Chang, Eric C., and Wilbur G, Lewellen. "Market Timing and Mutual Fund Investment Performance" Journal of Business, 57 (1984), 57-72.

Chen, Nai-fu, Richard Roll, and Stephen Ross. "Economic Forces and the Stock Market," Journal of Business, 59 (1986), 386-403.

Connor, Gregory, and Robert A. Korajczyk. "Risk and Return in an Equilibrium APT: Application of a New Test Methodology;' Journal of Financial Economics, 21 (1988), 255-289.

Cumby, Robert E., and David M. Modest. "Testing for Market Taming Ability: A Framework for Forecast Evaluation" Journal of Financial Economics, 19 (1987), 169-189.

DeBondt, Werner, and Richard Thaler. "Further Evidence on Investor Overreaction and Stock Market Seasonality," Journal of Finance, 42 (1987), 557-581.

Fama, E., and K. French. "Dividend Yields and Expected Stock Returns," Journal of Financial Economics, 22 (1988), 3-25.

Fama, E., and K. French. "Business Conditions and Expected Return on Stocks and Bonds," Journal of Financial Economics, 25 (1989), 23-49.

Fama, E., and G. William Schwert. "Asset Returns and Inflation;' Journal of Financial Economics, 5 (1977), 115-146. 
Ferson, W. "Changes in Expected Security Returns, Risk, and Level of Interest Rates,' Journal of Finance, 44 (1989), 1191-1217.

Ferson, W. "Are the Latent Variables in Time-Varying Expected Returns Compensation for Consumption Risk?" Journal of Finance, 45 (1990), 397-430.

Ferson, W., and C. Harvey. "The Variation of Economic Risk Premiums" Journal of Political Economy, forthcoming.

Ferson, Wayne, Shmuel Kandel, and Robert Stambaugh. "Test of Asset Pricing with TimeVarying Expected Risk Premiums and Market Betas," Journal of Finance, 42 (1987), 201-219.

Gibbons, Michael, R., and Wayne Ferson. "Testing Asset Pricing Models with Changing Expectations and an Unobservable Market Portfolio" Journal of Financial Economics, 14 (1985), 217-236.

Giliberto, S. Michael. "Equity Real Estate Investment Trust and Real Estate Returns" Journal of Real Estate Research, 5 (1990), 259-263.

Glascock, John L. "Market Conditions, Risk, and Real Estate Portfolio Returns: Some Empirical Evidence," Journal of Real Estate Finance and Economics, 4 (1991), 367-373.

Gyourko, Joseph, and Donald Keim. "What Does the Stock Market Tell Us About Real Estate Returns?" Working Paper, The Wharton School, 1991.

Harvey, Campbell R. "Time-Varying Conditional Covariances in Tests of Asset Pricing Models" Journal of Financial Economics, 24 (1989), 289-317.

Heuriksson, Roy D. "Market Timing and Mutual Fund Performance: An Empirical Investigation," Journal of Business, 57 (1984), 73-96.

Henriksson, Roy D., and Robert C. Merton. "On Market Timing and Investment Performance. 11. Statistical Procedures for Evaluating Forecasting Skills," Journal of Business, 54 (1981), 513-533.

Jensen, Michael C. "The Performance of Mutual Funds in the Period 1945-1964," Journal of Finance, 23 (1968), 389-416.

Keim, Donald B. "Size Related Anomalies and Stock Return Seasonality: Empirical Evidence" Journal of Financial Economics, 12 (1983), 13-32.

Keim, D., and R. Stambaugh. "Predicting Returns in the Stock and Bond Markets" Journal of Financial Economics, 17 (1986), 357-390. 
Liu, Crocker, and Jianping Mei. "Predictability of Returns on Equity REITs and Their CoMovement with Other Assets," Journal of Real Estate Finance and Economics, 5 (1992), 401408.

Liu, Crocker, and Jianping Mei. "An Analysis of Real Estate Risk Using the Present Value Model" Journal of Real Estate Finance and Economics, forthcoming.

Mei, Jianping. "A Semi-Autoregressive Approach to the Arbitrage Pricing Theory" Journal of Finance, forthcoming.

Mei, Jianping, and Anthony Saunders. "Bank Risk and Real Estate: An Asset Pricing Perspective" Working Paper, New York University, 1991.

Nourse, Hugh O. "The "Cap Rate," 1966-1984: A Test of the Impact of Income Tax Changes on Income Property," Land Economics, 63 (1987), 147-152.

White, Halbert. "A Heteroskedasticity-Consistent Covariance Matrix Estimator and a Direct Test for Heteroskedasticity," Econometrica, 48 (1980), 817-838. 